\title{
Providing Education Chronic Energy Deficiency (CED) Uses Web- Based She Smart to Improve Knowledge, Attitudes, and Practice in Adolescent Girls
}

\author{
Ananda \\ Midwifery Study Program, Graduate School of Hasanuddin University, Makassar, Indonesia \\ Corresponding author email: ananda19p@student.unhas.ac.id \\ Yusring Sanusi Baso \\ Learning Media Center, Learning Resource and E-Learning, Hasanuddin University, Makassar, Indonesia \\ Email: yusring@unhas.ac.id \\ Healthy Hidayanty \\ Department Of Nutrition Sciences, Faculty of Public Health, Hasanuddin University, Makassar, Indonesia \\ Email: hhidayanty@yahoo.com \\ Syafruddin Syarif \\ Department of Electrical Engineering, Faculty of Engineering, Hasanuddin University, Makassar, Indonesia \\ Email: syafruddin.s@eng.unhas.ac.id

\section{Aminuddin} \\ Department of Nutrition, Faculty of Medicine, Hasanuddin University, Makassar, Indonesia \\ Email: aminuddin@med.unhas.ac.id \\ Burhanuddin Bahar \\ Department Of Nutrition Sciences, Faculty of Public Health, Hasanuddin University, Makassar, Indonesia \\ Email: baharburhanuddin96@gmail.com
}

\begin{abstract}
One age category that is particularly susceptible to nutritional problems in adolescent girls. Globally, about $40 \%$ of deaths in developing countries are related to Chronic energy deficiency. Adolescents who experience a Chronic energy deficiency have an impact not only on the health of adolescent girls today but can have a long impact to become pregnant women and risk giving birth to a baby with low birth weight. This study to find out the effect of using chronic energy education models using web-based she Smart on knowledge, attitudes, and practice in adolescent girls. This study uses Pre-experimental Design, with a one-group pretest-posttest design. The sampling technique uses purposive sampling with a sample number of 47 respondents. This research was conducted in Senior High School 12 Makassar in September-October 2021. Analyze the data using the McNemar test. The results of statistical tests showed that there was an influence on the use of web-based She Smart education model of adolescent girls' knowledge of with $p$-value $=0.012(p<0.05)$, attitude with $p$-value $=0.031(p<0.05)$, and practice with $p$ value $=0.004$ ( $p<0.05)$. Chronic Energy Deficiency education models using the Web she smarts can increase knowledge, attitudes, and practice before and after adolescent interventions.

Keywords---CED, education, attitudes, adolescent girls, web-based.
\end{abstract}

ISSN 2632-9433

Submitted: 09 November 2021 |Revised: 27 December 2021| Accepted: 14 January 2022 56 
Introduction

Chronic energy deficiency is a state caused by an imbalance between consumption and needs (energy and protein). occurs due to lower energy consumption than the amount of energy needed by the body, which lasts for many years Chronic energy deficiency can be known from the value of the upper arm circumference limit which is $\leq 23.5 \mathrm{~cm}$ (Amalia et al. 2018; Mutaghfiroh et al. 2019; Paramashanti, 2020).

According to the World Health Organisation (WHO), reporting that the prevalence of chronic energy deficiency in adolescent girls globally reaches $35-75 \%$, WHO also reports that about $40 \%$ of deaths in developing countries are related to Chronic energy deficiency. Chronic energy deficiency incidence also occurs in countries such as Bangladesh, India, Indonesia, Myanmar, Nepal, Sri Lanka, and Thailand with a prevalence of $15-47 \%$. The country with the highest incidence of Chronic energy deficiency is Bangladesh with a prevalence of $47 \%$, while Indonesia is the 4th largest after India with a prevalence of $35.5 \%$ and the lowest incidence in Thailand with a prevalence of 1525\% (WHO, 2015).

Based on the Results of Basic Health Research (Riskesdas), the prevalence of Chronic energy deficiency incidence in Indonesia in 2013, in the age group of 15-19 years, namely Pregnant Women Of Childbearing Age By 38.5\%, And Women Of Childbearing Age Not Pregnant By 46.6\%. In 2018, In The Age Group Of 15-19 Years, Namely In Pregnant Women Of Childbearing Age By 33.5\%, And Women Of Childbearing Age Not Pregnant By 36.3\%. And According To The Results Of Basic Health Research (Riskesdas, 2018), In South Sulawesi, The Prevalence Of Risk Of Chronic Energy Deficiency Is Mostly In The Age Category Of 15-19 Years, Namely Pregnant Women Of Childbearing Age About 28.23\% And Women Of Childbearing Age Not Pregnant About 45.41\% (Riskesdas, 2018).

Theoretically, the factors that cause Chronic energy deficiency in adolescents consist of 2 (two) that are direct and indirect causes. Direct causes of Chronic energy deficiency are consumption patterns (eating intake), nutritional status, consumption of insufficient energy and protein, and the presence of infectious diseases (Reski et al., 2020; Shaheen \& Lindholm, 2006). While the indirect causal factors of Chronic energy deficiency are less socioeconomic, physical activity, education level, or lack of knowledge about nutrition and health and not access to nutritious food (Brown et al., 2011; Sediaoetama, 2000).

Adolescents who experience nutritional problems such as lack of Chronic energy deficiency can hurt their lives, such as a decrease in learning will, and a decrease in physical health. Adolescents who experience Chronic energy deficiency have an impact not only on the health of adolescent girls today but can have a long impact to become pregnant women and at risk of giving birth to a baby with low birth weight (Petrika et al., 2016; Pujiatun et al., 2014).

In connection with this problem, several efforts can be made to prevent the risk of chronic energy deficiency in adolescence, one of which is by doing nutrition education (Evans,2008; Calderhead, 1989). Nutrition education needs to be provided to adolescents and mothers-to-be to increase knowledge or information early on about Chronic energy deficiency and efforts in dealing with it and increasing knowledge about their nutritional intake for example by consuming foods that source energy, protein, fat, vitamins, and minerals both of quality and quantity (Amalia et al., 2018; Syukur, 2017; Notoatmodjo, 2012; Wardhani et al., 2021; Waryana et al., 2019).

According to research conducted by Fauziyah (2020), in Makassar City stated that adolescents who have less knowledge are more likely to occur a Chronic energy deficiency. Statistical test results found that respondents who have good nutrition knowledge have prevention 0.06 times against Chronic energy deficiency than respondents who have less nutritional knowledge ( $p=0.000,95 \% \mathrm{CI}=0.01-0.27$ ) (Umisah \& Puspitasari, 2017).

The research conducted by Lathifa (2020), conducted on X-grade high school students in Surabaya, stated that web-based nutrition education provided to students showed a better level of acceptance and also fondness when compared to using leaflet media. And there are also better changes in attitudes, and practices in students after being educated about web-based nutrition (Huang \& Zhao, 2020; Neff et al., 2002). It is proven that most of the respondents have a positive attitude of $(88.9 \%)$ and good practice by $(94.4 \%)$.

In this era of globalization, the use of Smartphones as a medium of communication technology gives a very important role in human life, one of which is in teenagers who are currently difficult to escape the use of gadgets (Sudiarto et al., 2019). Some studies say that the use of technology in the field of health can support the improvement of knowledge in a person about health information so quickly (Yani, 2018).

Therefore, an information system that can help and facilitate adolescent girls to be able to access information about Chronic energy deficiency problems in adolescent girls that can be accessed through desktop or mobile phones does not require certain qualifications or types of mobile phones and It does not require a large storage capacity and can be reached by everyone. Based on the description, researchers are interested in research to find out the influence 
of the use of Chronic energy deficiency using web-based she Smart on knowledge, attitudes, and practice in adolescent girls (Schinke et al., 2008; Miller \& Gur, 2002).

\section{Research Methods}

This study uses Pre-experimental Design, with a one-group pretest-posttest research design. The research was conducted in Senior High School Negeri 12 Makassar in September-October 2021. The population in this study is all adolescent girls class XI in Senior High School Negeri 12 Makassar which is as many as 152 people. Sampling technique using Purposive Sampling and obtained sample as many as 47 respondents obtained using the sloven's formula and who meet the criteria of inclusion. Data collection techniques are performed using primary data and secondary data. Primary data is obtained directly from respondents to get respondent information by conducting interviews and distributing questionnaires. Secondary data is obtained from library studies and data from research establishment agencies. Computerized data processing using the SPSS program version 21. Analyze the data using the McNemar Test. This research has received ethical approval from the ethics committee Faculty of Public Health, Hasanuddin University Makassar with number 7400/UN4.14.1/TP.01.02/2021.

\section{Results and Discussion}

Knowledge

Table 1

Influence of chronic energy lack of education using web-based She Smart on adolescent girl's knowledge (n=47)

\begin{tabular}{|c|c|c|c|c|c|c|c|}
\hline \multirow{3}{*}{$\begin{array}{l}\text { Pre } \\
\text { Test }\end{array}$} & \multicolumn{4}{|c|}{ Post Test } & \multirow{2}{*}{\multicolumn{2}{|c|}{ Total }} & \multirow{3}{*}{$p$} \\
\hline & \multicolumn{2}{|c|}{ Good } & \multicolumn{2}{|c|}{ Less } & & & \\
\hline & $\mathrm{n}$ & $\%$ & $\mathrm{n}$ & $\%$ & $\mathrm{n}$ & $\%$ & \\
\hline Less & 10 & 21,3 & 2 & 4,3 & 12 & 25,5 & \\
\hline Good & 34 & 72,3 & 1 & 2,1 & 35 & 74,5 & 0.012 \\
\hline Total & 44 & 93,6 & 3 & 6,4 & 47 & 100 & \\
\hline
\end{tabular}

*McNemar Test

Based on the results of statistical tests in table 1 showed that after the intervention, Adolescent Girls experienced a change in knowledge level from a lesser category to as many as 10 people $(21.3 \%)$ and a good category to less than 1 person $(2.1 \%)$. So, after the intervention the number of Adolescent Girls with good knowledge levels as many as 44 people $(93.6 \%)$ and fewer knowledge levels as many as 3 people $(6.4 \%)$. Based on the results of the static test is obtained a value of $p=0.012(p<0.05)$ which means there is knowledge before and after the provision of a web-based She Smart education model on Adolescent Girls' knowledge about chronic energy deficiency in Senior high school 12 of Makassar.

Attitude

Table 2

The effect of chronic energy-less education uses web-based She Smart on the attitudes of adolescent girls $(n=47)$

\begin{tabular}{|c|c|c|c|c|c|c|c|}
\hline \multirow{3}{*}{$\begin{array}{l}\text { Pre } \\
\text { Test }\end{array}$} & \multicolumn{4}{|c|}{ Post Test } & \multirow{2}{*}{\multicolumn{2}{|c|}{ Total }} & \multirow{3}{*}{$p$} \\
\hline & \multicolumn{2}{|c|}{ Good } & \multicolumn{2}{|c|}{ Less } & & & \\
\hline & $\mathrm{N}$ & $\%$ & $\mathrm{n}$ & $\%$ & $\mathrm{n}$ & $\%$ & \\
\hline Less & 6 & 12,8 & 1 & 2,1 & 7 & 14,9 & \\
\hline Good & 40 & 85,1 & 0 & 0,0 & 40 & 85,1 & 0.031 \\
\hline Total & 46 & 97,9 & 1 & 2,1 & 47 & 100 & \\
\hline
\end{tabular}

*McNemar Test 
Based on the results of statistical tests in table 2 showed that after the intervention, adolescent girls who experienced a change in attitude from a lesser category to 6 people $(12.8 \%)$ and a good category to less by $0.0 \%$. So, after the intervention the number of Adolescent Girls with the good attitude category as many as 46 people (97.9\%) and the number of Adolescent Girls with the attitude category less as much as 1 person (2.1\%). Based on the results of the static test obtained a value of $p=0.031(p<0.05)$ which means there is an influence on attitude before and after the provision of a web-based She Smart education model towards the attitude of Adolescent Girls about chronic energy deficiency in senior high school 12 of Makassar.

\section{Practice}

Table 3

Influence of chronic energy lack education use of web-based She Smart on the actions of adolescent girls $(\mathrm{n}=47)$

\begin{tabular}{|c|c|c|c|c|c|c|c|}
\hline \multirow{3}{*}{$\begin{array}{l}\text { Pre } \\
\text { Test }\end{array}$} & \multicolumn{4}{|c|}{ Post Test } & \multirow{2}{*}{\multicolumn{2}{|c|}{ Total }} & \multirow{3}{*}{$p$} \\
\hline & \multicolumn{2}{|c|}{ Positive } & \multicolumn{2}{|c|}{ Negative } & & & \\
\hline & $\mathrm{N}$ & $\%$ & $\mathrm{n}$ & $\%$ & $\mathrm{n}$ & $\%$ & \\
\hline Negative & 14 & 29,8 & 6 & 12,8 & 20 & 42,6 & \\
\hline Positive & 25 & 53,2 & 2 & 4,2 & 27 & 57,4 & 0.004 \\
\hline Total & 39 & 83 & 8 & 17 & 47 & 100 & \\
\hline
\end{tabular}

*McNemar test

Based on the results of statistical tests in table 3 showed that after the intervention, Adolescent Girls who experienced a change in practice from negative to positive as many as 14 people $(29.8 \%)$ and who experienced a change in practice from positive to negative as much as 2 people (4.2\%). So, after the intervention the number of Adolescent Girls with positive practice categories as many as 39 people (83\%) and the number of Adolescent Girls with negative practice categories as many as 8 people $(17 \%)$. Based on the results of the static test is obtained a value of $p=0.004(p<0.05)$ which means there is an effect of practice before and after the provision of a web-based She Smart education model on the actions of Adolescent Girls about chronic energy deficiency senior high school 12 in Makassar.

The influence of the use of chronic energy deficiency education using web-based She Smart on the knowledge of adolescent girls

Knowledge is the result of knowing, and that result will be obtained after someone senses a particular object. Sensing occurs through the human five senses, namely sight, sense, and touch (Nuryani \& Paramata, 2018). Based on the results of data analysis using the McNemar test, where obtained $p$-value $=0.012$ or $p<0.05$. So it can be concluded that there is an influence on the use of less chronic energy education models using web-based She Smart on knowledge in adolescent girls.

This is in line with research conducted by Waryana et al. (2019), which states the influence of providing counseling video media about the prevention of Chronic energy deficiency on the knowledge of adolescent girls. Likewise with research conducted by Norhasanah \& Dewi (2021), states that there is an effect of providing balanced nutrition to knowledge in adolescents with Chronic energy deficiency.

This is also in line with research conducted by Amalia et al. (2018), which states that there is an influence of nutritional education on a person's knowledge in preventing Chronic energy deficiency. Increased knowledge in a person occurs due to the influence of nutritional education provided. With the education process, then someone will learn to better understand those who initially do not know to know. So that there is a change in category for the better (Wardhani et al., 2021).

With the availability of education Chronic energy deficiency using web-based She Smart in adolescent girls is expected to have a positive impact in increasing awareness of adolescent girls to pay more attention to diet and consume a balanced nutritious diet. Because if a person already knows then a person will have the advantage to use the material that has been studied in real situations and circumstances. 
The influence of the use of chronic energy deficiency education using Web-based She Smart on the attitudes of Adolescent Girls

Attitude is a response or reaction that is still closed from someone to a particular object. Attitude has 4 stages, including accepting, responding, appreciating, and being responsible. Attitude is not a practice but a predisposition to the practice of a behavior (Herman et al., 2020; Notoatmodjo, 2012).

Based on the results of data analysis using the McNemar test where the value $p$-value $=0.031$ or $p<0.05$. It can be concluded that there is an effect on the use of the education model less chronic energy (CED) uses web-based She Smart against attitudes in adolescent girls. This is in line with research conducted by Norhasanah \& Dewi (2021), which states that there is an influence on the provision of balanced nutrition education on attitudes in adolescents with Chronic energy deficiency (Jacelon, 2002; Kristeller \& Hoerr, 1997).

Attitudes can be influenced by several aspects, including knowledge, beliefs, thoughts, personal experiences, mass media, culture, and emotions. Attitudes influence the tendency to form behavior that is if a person has a positive attitude, it tends to behave positively. Whereas if someone with a negative attitude, it tends to appear negative behavior (Yulianasari et al., 2019). Chronic energy deficiency education using web-based She Smart that has been given has been proven to increase knowledge and attitudes in adolescent girls about the prevention of Chronic energy deficiency, thus it is expected to also form good behavior in adolescent girls so that the condition of Chronic energy deficiency that exists can be resolved (Muslimin et al., 2022).

The effect of the use of Chronic energy deficiency education using web-based She Smart on the practice of adolescent girls

Based on the results of data analysis using the McNemar test were obtained the value $p$-value $=0.004$ or $p<0.05$. It can then be concluded that there is an influence on the use of chronic energy education models using web-based She Smart against the practice in adolescent girls. This is in line with research conducted by Amalia et al. (2018), which states that there are differences in practice before and after the provision of nutritional education about the prevention of chronic energy deficiency in mothers-to-be with research results value $p$-value $=0.003$ or $p<0.05$.

Changes in practice can occur after there is a change in knowledge and attitude in a person. Providing nutrition education is done with a good strategy that can increase knowledge and attitudes that will then be followed by changes in action. The formation of a new practice begins from the aspect of knowledge and reasoning which means that one needs to know in advance about the existing stimulus that is in the form of new material so that new knowledge arises which can then cause a response in the form of one's attitude that is expected from the results of a good attitude will arise good new practice as well (Amalia et al., 2018; Simbolon et al., 2019). With the web-based, she Smart for education Chronic energy deficiency in adolescent girls can have a positive impact on raising awareness in adolescent girls to prevent Chronic energy deficiency (Ernawati et al., 2022).

\section{Conclusion}

The model of Chronic energy deficiency education using web-based she Smart can increase knowledge, attitudes, and practice before and after the intervention in adolescent girls.

\section{Acknowledgments}

The researcher would like to express her thankfulness to all the staff and lecturers who helped the researcher by permitting her to do her research from September to October 2021 toward the student SMA Negeri 12 Makassar.

\section{References}

Amalia, F., Nugraheni, S. A., \& Kartini, A. (2018). Pengaruh edukasi gizi terhadap pengetahuan dan praktik calon ibu dalam pencegahan kurang energi kronik ibu hamil (Studi pada Pengantin Baru Wanita di Wilayah Kerja Puskesmas Duren, Bandungan, Semarang). Jurnal Kesehatan Masyarakat (E-Journal), 6(5), 370-377.

Brown, J. E., Isaacs, J. S., Krinke, U. B., Lechtenberg, E., Murtaugh, M. A., Sharbaugh, C., ... \& Wooldridge, N. H. (2011). Nutrition through the life cycle fourth edition. Belmont, USA: Thomson Learning Inc. Donnelly, Greene, Gibson, Smith.

Calderhead, J. (1989). Reflective teaching and teacher education. Teaching and teacher education, 5(1), 43-51. https://doi.org/10.1016/0742-051X(89)90018-8 
Ernawati, E., Baso, Y. S., Hidayanty, H., Syarif, S., Aminuddin, A., \& Bahar, B. (2022). The effects of anemia education using web-based she smart to improve knowledge, attitudes, and practice in adolescent girls. International Journal of Health \& Medical Sciences, 5(1), 44-49. https://doi.org/10.21744/ijhms.v5n1.1831

Evans, C. (2008). The effectiveness of m-learning in the form of podcast revision lectures in higher education. Computers \& education, 50(2), 491-498. https://doi.org/10.1016/j.compedu.2007.09.016

Fauziyah, N. S. (2020). The Influence of Parents and Other Factors on Adolescents' Fish Consumption in Selected Senior High School Students, Jakarta. Indian Journal of Public Health Research \& Development, 11(5).

Herman, H., Citrakesumasari, C., Hidayanti, H., Jafar, N., \& Virani, D. (2020). The Influence of Nutrition Education Using The Ministry of Health Leaflet on The Behavior of Vegetable and Fruit Consumption in Adolescents In Senior High School 10 Makassar. Journal of Indonesian Community Nutrition. The Journal of Indonesian Community Nutrition, 9(1), 39-50.

Huang, Y., \& Zhao, N. (2020). Generalized anxiety disorder, depressive symptoms and sleep quality during COVID19 outbreak in China: a web-based cross-sectional survey. Psychiatry research, 288, 112954. https://doi.org/10.1016/j.psychres.2020.112954

Jacelon, C. S. (2002). Attitudes and behaviors of hospital staff toward elders in an acute care setting. Applied Nursing Research, 15(4), 227-234. https://doi.org/10.1053/apnr.2002.35958

Kristeller, J. L., \& Hoerr, R. A. (1997). Physician attitudes toward managing obesity: differences among six specialty groups. Preventive medicine, 26(4), 542-549. https://doi.org/10.1006/pmed.1997.0171

Lathifa, S. (2020). The Effect of Web-Based Education Media Toward Balanced Nutritional Eating Behavior on High School Students in Surabaya. Media Gizi Kesmas, 9(2), 48-56.

Miller, L., \& Gur, M. (2002). Religiousness and sexual responsibility in adolescent girls. Journal of Adolescent Health, 31(5), 401-406. https://doi.org/10.1016/S1054-139X(02)00403-2

Muslimin, K. D., Baso, Y. S., Hidayanty, H., Syarif, S., Aminuddin, A., \& Bahar, B. (2022). The effect of HIV/AIDS education prevention using web-based she smart on knowledge, attitudes, and practice in adolescent girls. International Journal of Health \& Medical Sciences, 5(1), 31-36. https://doi.org/10.21744/ijhms.v5n1.1830

Mutaghfiroh, L., Sari, E. U. U., \& NorAzizah, Y. (2019). Dampak Sosial Ekonomi Dan Jarak Kelahiran Terhadap Kejadian Kurang Energi Kronik Pada Ibu Multigravida. Jurnal Ilmu Kebidanan dan Kesehatan (Journal of Midwifery Science and Health), 10(2).

Neff, M. M., Turk, E., \& Kalishman, M. (2002). Web-based primer design for single nucleotide polymorphism analysis. TRENDS in Genetics, 18(12), 613-615. https://doi.org/10.1016/S0168-9525(02)02820-2

Norhasanah, N., \& Dewi, A. P. (2021). Pendidikan Gizi Berpengaruh Terhadap Pengetahuan dan Sikap Mengenai Gizi Seimbang pada Remaja Putri Kurang Energi Kronik di Madrasah Aliyah Negeri 2 Banjar. Jurnal Kesehatan Indonesia, 11(3), 111-115.

Notoatmodjo, S. (2012). Health promotion and health behavior. Jakarta: rineka cipta.

Nuryani, N., \& Paramata, Y. (2018). Intervensi Pendidik Sebaya Meningkatkan Pengetahuan, Sikap, dan Perilaku Gizi Seimbang pada Remaja di MTsN Model Limboto. Indonesian Journal of Human Nutrition, 5(2), 96-112.

Paramashanti, B. A., \& Benita, S. (2020). Early introduction of complementary food and childhood stunting were linked among children aged 6-23 months. Jurnal Gizi Klinik Indonesia, 17(1), 1-8.

Petrika, Y., Hadi, H., \& Nurdiati, D. S. (2016). Tingkat asupan energi dan ketersediaan pangan berhubungan dengan risiko kekurangan energi kronik (KEK) pada ibu hamil. Jurnal Gizi dan Dietetik Indonesia (Indonesian Journal of Nutrition and Dietetics), 2(3), 140-149.

Pujiatun, T., Dyah Widowati, S. K. M., \& Ika Nur Mayorie, S. K. M. (2014). Hubungan Tingkat Konsumsi Energi dan Protein dengan Kejadian Kurang Energi Kronis (KEK) pada Siswa Putri di SMA Muhammadiyah 6 Surakarta (Doctoral dissertation, Universitas Muhammadiyah Surakarta).

Reski, R. N., Hadju, V., Indriasari, R., \& Muis, M. (2020). Anemia, chronic energy deficiency and their relationship in preconception women. Enfermería Clínica, 30, 76-80. https://doi.org/10.1016/j.enfcli.2020.06.018

Riskesdas. (2018). Riskesdas National Report. In the Agency for Health Research and Development.

Schinke, S. P., Fang, L., \& Cole, K. C. (2008). Substance use among early adolescent girls: Risk and protective factors. Journal of Adolescent Health, 43(2), 191-194. https://doi.org/10.1016/j.jadohealth.2007.12.014

Sediaoetama, A. D. (2000). Ilmu Gizi untuk Mahasiswa dan Profesi Jilid 2. DianRakyat, Jakarta.

Shaheen, R., \& Lindholm, L. (2006). Quality of life among pregnant women with chronic energy deficiency in rural Bangladesh. Health Policy, 78(2-3), 128-134. https://doi.org/10.1016/j.healthpol.2005.11.008

Simbolon, D., Rahmadi, A., \& Jumiyati, J. (2019). Pengaruh Pendampingan Gizi terhadap Perubahan Perilaku Pemenuhan Gizi Ibu Hamil Kurang Energi Kronik (KEK). Jurnal Kesehatan, 10(2), 269-275. 
Sudiarto, S., Niswah, F. Z., Pranoto, R. E. P., Hanifah, I., Enggardini, A. A., Masruroh, Z., \& Muhammad, H. N. A. (2019). Optimalisasi Pendidikan Kesehatan Kepada Remaja Melalui Aplikasi Android Profoteen. Jurnal Kepemimpinan dan Manajemen Keperawatan, 2(2), 74-79.

Syukur, N. A. (2017). Faktor-Faktor Yang Menyebabkan Kurang Energi Kronis (Kek) Pada Ibu Hamil di Puskesmas Sidomulyo Kota Samarinda. MMJ (Mahakam Midwifery Journal), 1(1), 38-45.

Umisah, I. N. A., \& Puspitasari, D. I. (2017). Perbedaan Pengetahuan Gizi Prakonsepsi dan Tingkat Konsumsi Energi Protein pada Wanita Usia Subur (WUS) Usia 15-19 Tahun Kurang Energi Kronis (KEK) dan Tidak KEK di SMA Negeri 1 Pasawahan. Jurnal Kesehatan, 10(2), 23-36.

Wardhani, D. A., Nissa, C., \& Setyaningrum, Y. I. (2021). Peningkatan Pengetahuan Remaja Putri Melalui Edukasi Gizi Menggunakan Media Whatsapp Group. Jurnal Gizi, 10(1), 31-37.

Waryana, W., Sitasari, A., \& Febritasanti, D. W. (2019). Intervensi media video berpengaruh pada pengetahuan dan sikap remaja putri dalam mencegah kurang energi kronik. AcTion: Aceh Nutrition Journal, 4(1), 58-62.

WHO. (2015). Regional Nutrition Strategy: Addressing malnutrition and micronutrient deficiencies (2011-2015).

Yani, A. (2018). Utilization of Technology in the Health of Community Health. PROMOTIF: Jurnal Kesehatan Masyarakat, 8(1), 97-103.

Yulianasari, P., Nugraheni, S. A., \& Kartini, A. (2019). Pengaruh Pendidikan Gizi Dengan Media Booklet Terhadap Perubahan Perilaku Remaja Terkait Pencegahan Kekurangan Energi Kronis (Studi pada Remaja Putri SMA Kelas XI di SMA Negeri 14 dan SMA Negeri 15 Kota Semarang). Jurnal Kesehatan Masyarakat (e-Journal), 7(4), 420-428. 